\title{
The Effect of Different Levels of Sesame Oil on Productive Performance, Egg Yolk and Blood Serum Lipid Profile in Laying Hens
}

\author{
Nguyen Duy Hoan, Mai Anh Khoa \\ Faculty of Animal Husbandry-Veterinary, Thai Nguyen University of Agriculture and Forestry, Thai Nguyen \\ City, Vietnam \\ Email:ndhoan@Irc-tnu.edu.vn
}

Received 29 December 2015; accepted 24 January 2016; published 27 January 2016

Copyright (C) 2016 by authors and Scientific Research Publishing Inc.

This work is licensed under the Creative Commons Attribution International License (CC BY). http://creativecommons.org/licenses/by/4.0/

(c) † Open Access

\section{Abstract}

Addition of sesame oil into layer diets has been proved to enrich the proportion of polyunsaturated fatty acids in animal's products. In this study, the effects of different levels of sesame oil in the diets on the performance, egg yolk and blood serum lipid profile of Isa Brown laying hens were investigated. A total of 96 layers were assigned into 4 groups to receive either 1 of 4 different diets contained $0.0 \%, 1.5 \%, 3.0 \%$ and $4.5 \%$ sesame oil, respectively. Sample of 12 eggs obtained from each groups were assessed for egg quality. The egg yolk fatty acid profile was determined with gas chromatography. Results revealed that the higher levels of sesame oil in the diet decreased egg production, egg weight, and egg yolk color except feed conversion ratio. In addition, supplementation of sesame oil increased the flow index of the eggs and the Haugh unite. The egg yolk lipid profile was not significantly different in the sesame oil fed groups, whereas, compare to control, it decreased the level of cholesterol. The blood serum lipid profile decreased in the sesame oil groups compare to control group. Meanwhile, monoacildigliserol also decreased in the sesame addition groups. In parallel with increasing levels of sesame oil, monounsaturated fatty acid (oleic acid) in the egg yolks significantly increased compared to the control $(37.00 \%, 42.89 \%, 42.20 \%$ and $43.48 \%$, respectively). It can be implied that sesame oil supplementation into the laying hens diet is necessary to produce monounsaturated fatty acid (MUFA) enriched eggs.

\section{Keywords}

Sesame Oil, Egg Yolk Lipid Profile, Performance, Laying Hens

\section{Introduction}

Addition of vegetable oil into layers diet has been world widely used in order to increase absorption of fat so-

How to cite this paper: Hoan, N.D. and Khoa, M.A. (2016) The Effect of Different Levels of Sesame Oil on Productive Performance, Egg Yolk and Blood Serum Lipid Profile in Laying Hens. Open Journal of Animal Sciences, 5, 85-93. 
luble vitamin (A, D, E, K), minerals and to enhance egg production. On the other hand, this addition is also for the seeking of production of functional nutrient enriched egg in poultry industry, in which, it is desired to reduce cholesterol concentrations in egg for those consumers who need to lower their dietary cholesterol intake. It has been known that the supplementation of vegetable oil provided essential fatty acid precursor, which cannot be synthesized by animal or human. It has been proved that the supplemental oils significantly altered egg yolk lipid profiles or lipid composition ratios [1] [2]. These essential fatty acids are commonly found in some animal oils such as fish oil and vegetable oils such as sesame oil, canola oil, soybean oil etc. Sesame seed was described to have originated from Africa and it is thought to be the oldest oil seed known to man. Sesame oil is very resistant to rancidity due to the presence of natural anti-oxidants such as sesamolin, sesamin, and sesamol. It is therefore useful in increasing the shelter life of margarine and other vegetable oil products. Sesame oil is plant-derived oil rich in oleic acid (53.8\%) which is a monounsaturated fatty acid [3]. However, it also contains a significant amount of linoleic (22.1\%) and alpha-linoleic fatty acids. Sesame oil has been considered as a perfect balance of $n-6$ to $n-3$ polyunsaturated fatty acids (PUFAs), in which $54.68 \%$ of this ratio has been found matched human requirements. The egg yolk lipid profiles have been shown to vary depending on number of factors including genetic selection of the laying hen [4]. However, the results of genetic selection for lower cholesterol concentration in eggs also associated with lower egg production [5]. In order to modify egg yolk cholesterol and fatty acids contents, the nutritional strategies or dietary manipulations have been carried out, in which supplementary of different dietary oils supplementation in layer diets such as flaxseed, perilla oil, fish oil, vegetable oil have given some promising effects. Addition of sesame oil was also considered in several studies because of its rich in omega-3 fatty acids [6]-[8]. As the result, this supplement increased the amount of omega-3 in the form of alpha-linoleic fatty acid in egg, animal organs and tissue [9]. In addition, it also resulted in better proportion of n-3 PUFAs [10]. The present of omega-3 in the animal diet was also believed to improve the taste of animal's products (meat and egg) [11]. However, there is still little known how different levels of sesame oil would alter egg yolk lipid profile and the composition of monounsaturated fatty acids (MUFAs) in the egg yolk. Therefore, the aim of this study was to investigated the effect of different levels of sesame oil $(1.5 \%, 3.0 \%$ and $4.5 \%$ ) in layer diet on laying performance such as egg production, egg weight, feed intake, feed conversion ratio, egg quality, egg yolk lipid profile and composition of MUFAs.

\section{Materials and Methods}

\subsection{Experimental Materials and Diets}

The experiment was conducted on 96 laying hens of Isa Brown at 40 weeks of age when experimental birds reached the peak of egg production. All birds were selected to obtain uniformity of $93 \%$ then randomly allocated in six replicates groups caging $(50 \mathrm{~cm} \times 46 \mathrm{~cm} \times 46 \mathrm{~cm})$ consist of 4 birds per cage to receive either one of four diets containing $0.0 \%, 1.5 \%, 3.0 \%$ and $4.5 \%$ sesame oil, respectively. All birds were cared in comply with the MARD Vietnam standard (2010) [12]. The basal diet (Table 1) was formulated to meet the NRC 1994 recommendations [13]. Basal diet containing $1.5 \%$ soybean oil was considered as a control group. In the experimental groups, different levels $(0.0 \%, 1.5 \%, 3.0 \%$ and $4.5 \%$ of sesame oil) were supplemented into the basal diet. The fatty acid composition of sesame oil used in the current study is presented in Table 2 . The diets were stored in cold conditions (minus $4^{\circ} \mathrm{C}$ to $0^{\circ} \mathrm{C}$ ). Thus, addition of antioxidant to prevent oil degradation was not required. The metabolizable energy level (ME) of the feeds was calculated by the following formula which is described in Vietnamese National Standards (TCVN 8762/2011) [14]:

$$
\mathrm{ME}(\mathrm{MJ} / \mathrm{kg})=0.1551 \times \% \text { crude protein }+0.3431 \times \% \text { crude fat }+0.1669 \times \% \text { starch }+0.1301 \times \% \text { sugar. }
$$

During the 3 months of experiment, the hens were fed ad libitum once daily at 07:30 with free access to water. The hens were housed in cages that luminated 17 hours per day. The ethical approval of using animal in experiment was not applicable in this study since there are not any of such regulations in effect in Vietnam.

\subsection{Egg Quality Analysis and Collection of Samples}

The composition of the feed samples were analyzed for dry matter (DM), Crude protein (CP), Crude fat (CF), Neutral Detergent Fiber (NDF) and ash contents [15]. Feed intake and egg production were recorded daily; egg weight was measured weekly. Before the determination of egg weight, a sample of 12 eggs from each experimental group was stored for 24 hours at room temperature. The feed conversion ratio was expressed as the kilo- 
Table 1. Chemical compositions and compound of experimental diets (\%).

\begin{tabular}{|c|c|c|c|c|}
\hline Items & Control & $1.5 \%$ sesame oil & $3.0 \%$ sesame oil & $4.5 \%$ sesame oil \\
\hline Yellow corn & 52.00 & 52.00 & 52.00 & 46.00 \\
\hline Soybean meal & 21.59 & 21.59 & 22.50 & 22.50 \\
\hline Barley & 2.00 & 2.00 & - & 2.00 \\
\hline Wheat bran & 10.22 & 10.22 & 9.92 & 12.42 \\
\hline Calcium carbonate & 7.95 & 7.95 & 7.95 & 7.95 \\
\hline Sesame oil & - & 1.50 & 3.00 & 4.50 \\
\hline Soybean oil & 1.50 & - & - & - \\
\hline Full fat soybean & 2.50 & 2.50 & 2.50 & 2.50 \\
\hline DCP & 1.32 & 1.32 & 1.32 & 1.32 \\
\hline Salt & 0.40 & 0.40 & 0.29 & 0.29 \\
\hline Vit.+Min. & 0.20 & 0.20 & 0.20 & 0.20 \\
\hline D-L Methionine & 0.12 & 0.12 & 0.12 & 0.12 \\
\hline Antioxidant & 0.20 & 0.20 & 0.20 & 0.20 \\
\hline $\mathrm{ME}, \mathrm{kcal} / \mathrm{kg}^{* *}$ & 2762 & 2760 & 2868 & 2876 \\
\hline Crude Protein (\%) & 16.54 & 16.63 & 16.32 & 16.75 \\
\hline Ether Extract (\%) & 11.53 & 11.18 & 11.41 & 12.35 \\
\hline Crude ash (\%) & 10.93 & 9.84 & 11.42 & 10.69 \\
\hline Dry matter (\%) & 87.16 & 87.36 & 87.56 & 86.48 \\
\hline
\end{tabular}

*Each kilogram of feed: 12,000 IU Vitamin A, 2500.00 IU Vitamin D3, 30.000 mg Vitamin E, 34.000 mg Vitamin K, 3.000 mg Vitamin B1, 6.000 mg Vitamin B2, 30.000 mg Nicotinamide, 10.000 mg Cal.-D-Palm, 5.000 mg Vitamin B6, 15 mg Vitamin B12, 1.000 mg Folic Acid, 50 mg D-Biotin, $300.000 \mathrm{mg}$ Cholin, $50.000 \mathrm{mg}$ Vitamin C, $80.000 \mathrm{mg}$ Manganese (Mn), $60.000 \mathrm{mg}$ Iron (Fe), $60.000 \mathrm{mg}$ Zinc (Zn), $5.000 \mathrm{mg}$ Copper (Cu), 2.000 mg Iodine (I), $500 \mathrm{mg}$ Cobalt (Co), $150 \mathrm{mg}$ Selenium (Se), $1000 \mathrm{mg}$ Antioxidan. ${ }^{* *}$ Calculated analysis. DCP: Dicalcium phosphate.

gram of feed consumed per kilogram of egg produced. Another 12 egg samples were randomly collected from each experimental group every month in order to assess egg quality parameters. Egg quality parameters include shape index, shell strength, shell thickness, albumen index, yolk index, yolk color (Yolk Colour Fan, the CIE standard colorimetric system, F. Hoffman-La Roche Ltd., Basel, Switzerland) and Haugh unit. These parameters were calculated using following formulas as summarized by Ergun et al. (1987) [16]. Egg quality parameters were assessed using the following formulas:

$$
\text { Shape index }(100)=[\text { egg width }(\mathrm{cm}) / \text { egg length }(\mathrm{cm})] \times 100 .
$$

Shell strength $(\mathrm{kg} / \mathrm{cm} \times \mathrm{cm})$ determined by using a machine with a spiral pressure system; Shell thickness $(\mathrm{mm})$ was determined in 3 different parts (upper and lower ends and middle) using a micrometer.

Albumen index $(\%)=[($ albumen height $(\mathrm{mm}) /$ average of albumen length $(\mathrm{mm})$ and albumen width $(\mathrm{mm})] \times$ 100 ; Yolk index $(\%)=[($ yolk height $(\mathrm{mm}) /$ yolk diameter $(\mathrm{mm})] \times 100$; Yolk color was determined using commercially available yolk colour fan according to the CIE standard colorimetric system; Haugh unit $=100 \times \log$ $(\mathrm{H}+7.57-1.7 \times \mathrm{W} 0.37)$, where $\mathrm{H}=$ albumen height $(\mathrm{mm})$ and $\mathrm{W}=$ egg weight $(\mathrm{g})$.

Lipid oxidation was assessed on the basis of the MDA (Malondialdehit) formed during refrigerated storage. MDA was the compound used as an index of lipid peroxidation [17].

\subsection{Fatty Acids and Blood Analysis}

Blood samples were collected by venipuncture from the sub-wing vein and placed in non-additives blood collection tubes to produce serum from a sub-sample of 5 randomly selected laying hens from each treatment groups 
Table 2. Fatty acids composition (\%) of sesame oil included in the diets of laying hen.

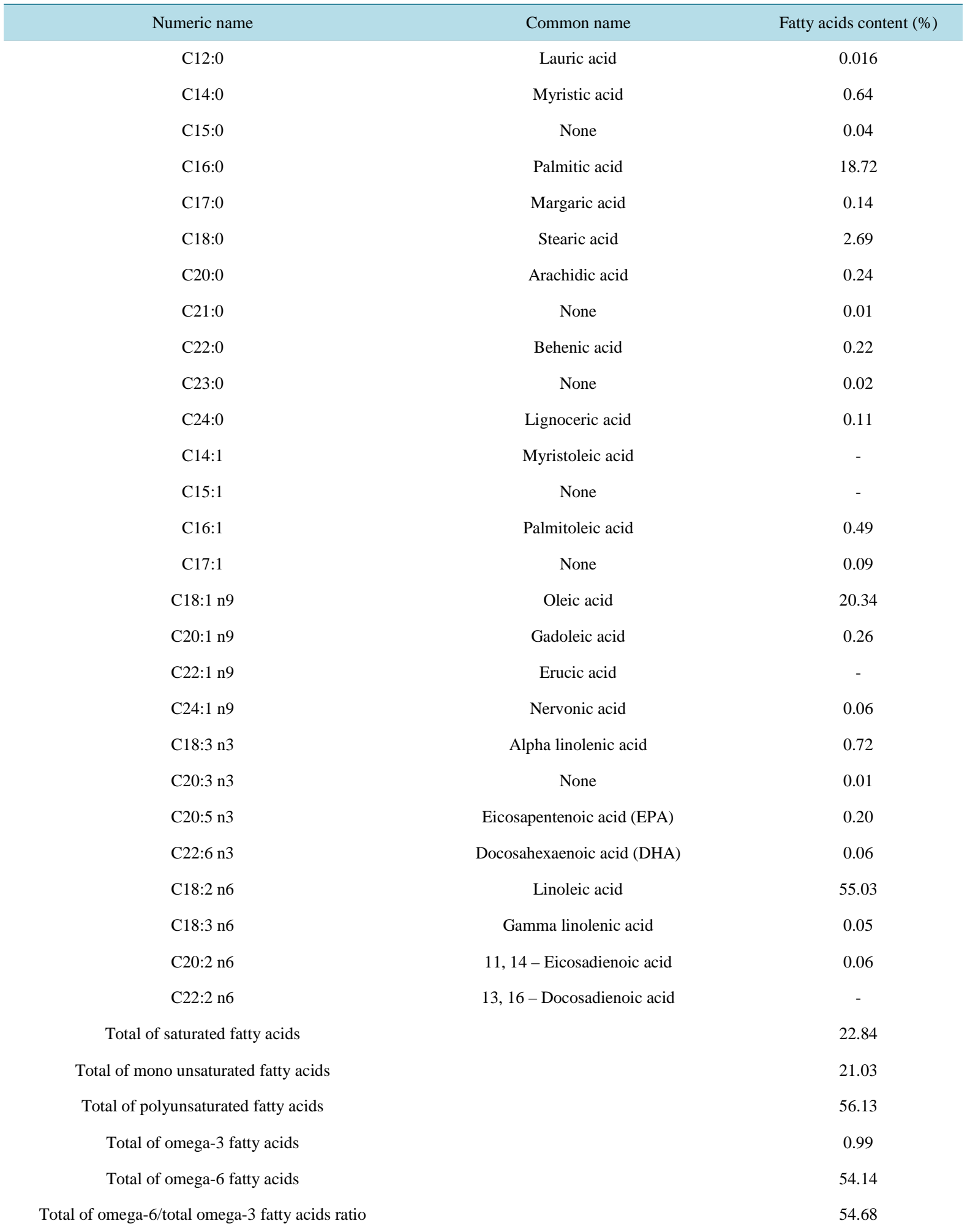

at the end of experiment period. Serum was separated by centrifugation at $3000 \mathrm{rpm}$ for 10 minutes and analyzed for blood lipid a profile includes: Hydrocarbons, Triachyleglyserol, free fatty acids, cholesterol, mono- 
diacilgliserol and pola lipid.

Fatty acids were analyzed by gas chromatography at the Institute of Biotechnology and Food Technology, Hanoi Vietnam. Fat ( 0.15 to $0.20 \mathrm{~g}$ ) extracted by the ether method from each sample (total of two), was saponified with $5 \mathrm{ml} \mathrm{NaOH}$ with methanol in a water bath for 10 minutes. Previously, at this mixture $5 \mathrm{~mL}$ BF3-methanol was added and the extraction process was refluxed for 2 minutes. After adding $5 \mathrm{~mL}$ heptane to the mixture, it was boiled again for 1 minute. The content of this mixture was transferred into $25 \mathrm{~mL}$ volumetric flasks and the volume was adjusted with saturated $\mathrm{NaCl}$ to $25 \mathrm{ml} .1 \mathrm{~mL}$ of the heptane phase from upper layer of the volumetric flasks was used to determine the fatty acids composition. Fatty acids were analyzed with gas chromatography (Agilent 6890N, Hewlett Packard, Palo Alto, CA) with a capillary column (supel covax 10, $60 \mathrm{~m} \times$ $0.25 \mathrm{~mm}$ ID). The chromatographic conditions were: detector temperature $280^{\circ} \mathrm{C}$; injector temperature $200^{\circ} \mathrm{C}$; initial column temperature $100^{\circ} \mathrm{C}$ for $8 \mathrm{~min}$, programmed to increase at a rate of $5^{\circ} \mathrm{C}$ per five minutes up to $200^{\circ} \mathrm{C}$ and then at $4^{\circ} \mathrm{C}$ per minute up to the final temperature of $250^{\circ} \mathrm{C}$. The helium carrier gas flow was set at $1.2 \mathrm{~mL} / \mathrm{min}$, hydrogen at $30 \mathrm{~mL} / \mathrm{min}$ and air at $300 \mathrm{~mL} / \mathrm{min}$. Injection of the $1-\mu \mathrm{L}$ samples was performed with a split ratio of 20:1. Identification of individual fatty acids was based on comparisons of retention times of unknown peaks to authentic fatty acid methyl ester standards.

\subsection{Statistical Analysis}

Differences between groups were analyzed with one-way analysis of variance (ANOVA) by using the statistical package SPSS for Windows (1999), version 10.0. Significant means were subjected to a multiple comparison test (Duncan) at alpha level 0.01 and 0.05 .

\section{Results and Discussion}

\subsection{Laying Performance of Experiment Birds}

Additional of oil to balance the energy level in the diet has been widely practiced in commercial animal feeds industry. In this study, the expectation of sesame oil is to alter the egg nutrient composition toward "healthier lipid profile" and should maintain animal performance. Laying performance of laying hens depends on several factors includes breed, live weight, age and energy level of the ration. In our study, laying performance of experiment birds such as egg production, egg weight; feed intake were decreased with the supplementation of different dietary sesame oil levels $(\mathrm{p}<0.05)$ egg but not for the feed conversion ratio (Table 3). The lower feed intake of birds which seen in birds fed diet contained $3.0 \%$ and $4.5 \%$ sesame oil might be due to the higher concentration of energy level in these diet compared to diet contained $1.5 \%$ sesame oil and in the control ( $<<0.05$ ), although feed conversion ratio was not affected by supplementing sesame oil. Our study finding was supported by the findings from Cherian, 2008 [18] when study on supplementation of n-3 fatty acid-rich oil into diet in Cobb laying hens in which the results also indicated that the different levels of oil supplemented in the diet also negatively affected layers performance. When increase the levels of oil supplemented in the diet this also resulted in increased level of energy level of the ration thus egg production, egg weight, and feed intake decreased [6]. This can also be explained that the shortage of linoleic acid in the diet might be the limiting factor contributed to the decrease in egg weight [19] [20]. Supplementation of different oils levels into diet had decreased feed intake [9], egg weight [21], feed conversion was not affected by supplementation [22] [23]. The data obtained from this study were consistent with some research findings that reported a decrease in egg weight [18] [19] [23] [24] when sesame oil was supplemented into diet for laying hens.

\subsection{The Effect of Sesame Oil on Egg Quality}

The egg quality was expressed in several criteria such as shape index, breaking strength, shell thickness, shell weight, yolk color, yellow index, flow index, Haugh unit, egg yolk lipid profile and egg yolk fatty acid composition. These parameters depend greatly on diet composition rather than just energy levels. It can be seen from our study that increased levels of sesame oil in the diet did not affect the shape index, breaking strength, shell thickness; shell weight and yolk color index. However, supplementation of sesame oil increased the flow index of the eggs and the Haugh unite (Table 4). These findings of our study were in contrast with some other findings in which it was reported that these parameters were improved with the supplementation of different dietary oil levels [25]. 
Egg yolk colour in the experimental groups decreased by approximately $20 \%$ compared to the control $(\mathrm{p}<$ 0.05 ) and this was similar among the groups. This difference is thought to be related to the amount of xanthophylls in the ration [26].

The egg yolk and blood serum lipid profile values are presented in Table 5 and Table 6 . The egg yolk lipid profile was not different among treatment groups in terms of hydrocarbons, although hydrocarbons in serum lipid profile increased in sesame oil fed groups. No statistical differences were observed among groups for free fatty acids, although free fatty acids were identified as being lower in the $4.5 \%$ sesame oil group compared to the control group. Identified blood serum and egg yolk cholesterol in egg yolks from the sesame oil groups was observed to be higher than the control group. In addition to the different oil levels, the type of supplement oils also affects cholesterol levels in the egg yolk [8]-[24]. The amount of egg yolk cholesterol Increased because of the decrease in lipogenesis with fatty acids, although the cholesterol level increased in the liver. Therefore, it is increased in the egg yolk [1].

Table 3. Egg production, egg weight, feed intake and feed conversion ratio of trial groups.

\begin{tabular}{ccccc}
\hline Groups & EP $(\%)$ & EW $(\mathrm{g})$ & FI (g) & FCR $(\mathrm{kg})$ \\
\hline Control & $83.68^{\mathrm{a}}$ & $65.21^{\mathrm{a}}$ & $126.76^{\mathrm{a}}$ & 1.53 \\
$1.5 \%$ sesame oil & $80.22^{\mathrm{a}}$ & $64.09^{\mathrm{a}}$ & $127.06^{\mathrm{a}}$ & 1.56 \\
$3.0 \%$ sesame oil & $78.18^{\mathrm{ab}}$ & $62.22^{\mathrm{b}}$ & $121.05^{\mathrm{b}}$ & 1.48 \\
$4.5 \%$ sesame oil & $74.77^{\mathrm{b}}$ & $61.58^{\mathrm{b}}$ & $120.09^{\mathrm{b}}$ & 1.50 \\
SEM & 2.76 & 0.59 & 3.00 & 0.06 \\
\hline
\end{tabular}

a, b, c: Means with different superscripts in the same column differs significantly p < 0.05. EP: Egg Production, EW: Egg Weight, FC: Feed Intake, FCR: Feed Conversion Ratio.

Table 4. The effects of sesame oil on egg quality.

\begin{tabular}{cccccc}
\hline Groups & Control & $1.5 \%$ sesame oil & $3.0 \%$ sesame oil & $4.5 \%$ sesame oil & SEM \\
\hline Quality criteria & & & & & \\
SI (\%) & 74.53 & 73.54 & 74.65 & 74.33 & 0.84 \\
BS (kg/cm $\left.{ }^{2}\right)$ & 2.19 & 1.58 & 2.01 & 1.85 & 0.17 \\
ST(mm) & 0.39 & 0.38 & 0.38 & 0.38 & 0.01 \\
SW(g) & 7.88 & 7.90 & 7.62 & 7.66 & 0.17 \\
YC & $8.01^{\mathrm{a}}$ & $6.64^{\mathrm{ab}}$ & $6.65^{\mathrm{ab}}$ & $6.58^{\mathrm{ab}}$ & 0.14 \\
YI(\%) & 38.66 & 39.70 & 41.20 & 40.99 & 0.42 \\
FI(\%) & $7.98^{\mathrm{b}}$ & $9.09^{\mathrm{a}}$ & $8.56^{\mathrm{b}}$ & $9.10^{\mathrm{a}}$ & 0.40 \\
HU & $79.00^{\mathrm{b}}$ & $82.69^{\mathrm{ab}}$ & $81.08 \mathrm{a}^{\mathrm{b}}$ & $83.32^{\mathrm{a}}$ & 1.48 \\
\hline
\end{tabular}

a, b, c: Means with different superscripts each column differs significantly p < 0.05. SI: Shape index; BS: Breaking Strength; ST: Shell Thickness; SW: Shell Weight; YC: Yolk Colour; YI: Yellow Index; FI:Flow Index; HU: Haugh Unit.

Table 5. The egg yolk lipid profile (\%).

\begin{tabular}{ccccccc}
\hline Groups & HC & TAG & FFA & Col & M-DAG & PL \\
\hline Control & 9.19 & $65.27^{\mathrm{a}}$ & 3.86 & $15.20^{\mathrm{b}}$ & 5.14 & 1.01 \\
$1.5 \%$ sesame oil & 9.55 & $63.44^{\mathrm{b}}$ & 3.99 & $16.66^{\mathrm{a}}$ & 5.45 & 1.06 \\
3.0\% sesame oil & 9.42 & $64.48^{\mathrm{ab}}$ & 3.33 & $17.11^{\mathrm{a}}$ & 5.01 & 0.82 \\
$4.5 \%$ sesame oil & 9.09 & $63.94^{\mathrm{b}}$ & 3.35 & $17.70^{\mathrm{a}}$ & 5.24 & 0.81 \\
SEM & 0.32 & 0.42 & 0.25 & 0.38 & 0.28 & 0.09 \\
\hline
\end{tabular}

a, b, c: Means with different superscripts in the same column differs significantly p < 0.05. HC: Hydrocarbons; TAG: Triachyleglyserol; FFA: Free Fatty Acids; Col: Cholesterol; M-DAG: Mono-Diaçilgliserol; PL: Polar Lipids. 
Differences level of feed oils on egg yolk cholesterol levels are thought to be related to the genetic structure of chickens with factors connected to the diet. The supplement of sesame oil had significantly altered fatty acids composition of egg yolk in this study. Especially, supplement of sesame oil had significantly increase level of Linoleic acid $(\mathrm{p}<0.05)$ but not that of Oleic acid, whereas, it decreased the alpha-linoleic acid in the egg yolk. The lowest amount of oleic acid was determined in the control group (37.0\%), while the highest amount was in the group with $4.5 \%$ sesame oil (43.48\%). Conversely, the highest amount of linoleic and alpha-linoleic acid (20\% $22 \%$ and $0.90 \%$, respectively) were found in the control group, the lowest amount of linoleic and alpha-linoleic acid were also found in the group with $4.5 \%$ sesame oil. No statistical differences were observed among groups for Eicosapentaenoic acid (EPA) and Docosapentaenoic acid (DHA), as well as total Saturate Fatty Acids (SFA). Polyunsaturated Fatty Acids (PUFA) in the groups with sesame oil was decreased $(\mathrm{p}<0.05)$ compared to the control. It can be observed that the levels of n-3 PUFAs in diets did not affect the egg yolk fatty acid profile (PUFAs, MUFAs and SFAs) [7]-[18]. It is readily that egg yolk lipid profile depends on the type and levels of oil supplemented. It was reported that egg yolk MUFAs level was higher when chickens fed with tallow oil and olive oil. The similar trend also observed for egg yolk PUFA level when soybean oil and flax seed oil were supplemented [21]. An increase in the PUFA of egg yolk was believed to be associated to the high level of linoleic acid in soybean and flaxseed oil [22]. In our study, it was determined that the amounts docosapentanoic acid (DPA, C22:5n-3) and docosahexanoic acid (DHA, C22:6n-3) were highest in the group with $4.50 \%$ sesame oil $(1.50 \%)$ and lowest in the control $(0.90 \%)$ (Table 7$)$ [25]. It can be explained by the different of oil profile

Table 6. The blood serum lipid profile (\%).

\begin{tabular}{ccccccc}
\hline Groups & HC & TAG & FFA & Col & M-DAG & PL \\
\hline Control & $17.86^{\mathrm{c}}$ & $45.67^{\mathrm{a}}$ & $4.29^{\mathrm{bc}}$ & $20.11^{\mathrm{ab}}$ & $2.20^{\mathrm{a}}$ & $9.89^{\mathrm{b}}$ \\
$1.5 \%$ & $22.09^{\mathrm{b}}$ & $39.32^{\mathrm{b}}$ & $3.80^{\mathrm{c}}$ & $20.58^{\mathrm{a}}$ & $1.76^{\mathrm{b}}$ & $12.00^{\mathrm{a}}$ \\
$3.0 \%$ & $24.11^{\mathrm{b}}$ & $37.90^{\mathrm{b}}$ & $5.57^{\mathrm{ab}}$ & $19.30^{\mathrm{bc}}$ & $1.70^{\mathrm{b}}$ & $11.96^{\mathrm{a}}$ \\
$4.5 \%$ & $27.29^{\mathrm{a}}$ & $34.66^{\mathrm{c}}$ & $6.00^{\mathrm{a}}$ & $18.66^{\mathrm{c}}$ & $1.72^{\mathrm{b}}$ & $11.42^{\mathrm{ab}}$ \\
SEM & 0.93 & 0.86 & 0.44 & 0.33 & 0.15 & 0.50 \\
\hline
\end{tabular}

a, b, c: Means with different superscripts each columns differ significantly p < 0.05. HC: Hydrocarbons; TAG: Triachyleglyserol; FFA: Free Fatty Acids; Col: Cholesterol; M-DAG: Mono-Diacilgliserol; PL: polar lipid.

Table 7. The effects of sesame oil on egg yolk fatty acid composition (\%).

\begin{tabular}{|c|c|c|c|c|c|}
\hline Fatty acids & Control & $1.5 \%$ sesame oil & $3.0 \%$ sesame oil & $4.5 \%$ sesame oil & SEM \\
\hline C14:0 (miristic acid) & $0.26^{\mathrm{b}}$ & $0.32^{\mathrm{a}}$ & $0.28^{\mathrm{ab}}$ & $0.26^{\mathrm{b}}$ & 0.299 \\
\hline C16:1 T7 (palmitoleic acid) & $2.18^{\mathrm{ab}}$ & $2.33^{\mathrm{a}}$ & $1.88^{\mathrm{b}}$ & $1.25^{\mathrm{c}}$ & 0.103 \\
\hline C18:1 T9 (oleic acid) & $37.00^{\mathrm{b}}$ & $42.89^{\mathrm{a}}$ & $42.20^{\mathrm{a}}$ & $43.48^{\mathrm{a}}$ & 0.528 \\
\hline C18:2 T6 (linoleic acid) & $20.22^{\mathrm{a}}$ & $13.79^{b}$ & $14.11^{\mathrm{b}}$ & $14.22^{\mathrm{b}}$ & 0.788 \\
\hline C18:3 T3 (alpha-linolenic acid) & $0.90^{\mathrm{a}}$ & $0.52^{\mathrm{c}}$ & $0.66^{\mathrm{b}}$ & $0.69^{\mathrm{b}}$ & 0.055 \\
\hline C20:5 T3 (EPA) & 0.05 & 0.04 & 0.03 & 0.03 & 0.006 \\
\hline C22:5 T3 (DPA) & 0.10 & 0.11 & 0.12 & 0.11 & 0.014 \\
\hline C22:6 T3 (DHA) & $0.90^{c}$ & $0.83^{\mathrm{c}}$ & $1.14^{\mathrm{b}}$ & $1.50^{\mathrm{a}}$ & 0.050 \\
\hline GSFA & 34.55 & 33.88 & 34.59 & 33.46 & 1.033 \\
\hline GMUFA & $40.0^{\mathrm{b}}$ & $47.58^{\mathrm{a}}$ & $46.21^{\mathrm{a}}$ & $46.6^{\mathrm{a}}$ & 0.541 \\
\hline GPUFA & $24.51^{\mathrm{a}}$ & $17.72^{\mathrm{b}}$ & $18.32^{\mathrm{b}}$ & $19.95^{b}$ & 0.948 \\
\hline GT6 & $22.56^{\mathrm{a}}$ & $16.22^{\mathrm{b}}$ & $16.37^{\mathrm{b}}$ & $16.62^{\mathrm{b}}$ & 0.859 \\
\hline GT3 & $1.95^{\mathrm{b}}$ & $1.50^{\mathrm{c}}$ & $1.95^{\mathrm{b}}$ & $2.33^{\mathrm{a}}$ & 0.097 \\
\hline
\end{tabular}

a, b, c: Means with different superscripts in the same column differs significantly $\mathrm{p}<0.05$. 
in the diet [26]. In this study, a high amount of MUFA and a low amount of PUFA were observed in the experimental group. This explained by the differences in the fatty acid profile of sesame oil [21] [27]-[30].

\section{Conclusion}

Our results indicated that increasing levels of sesame oil in layer diet had negative effect on egg production, egg weight, feed intake and yolk color. Nevertheless, it is important in producing monounsaturated fatty acid (MUFAs) enrich eggs with lower cholesterol levels. Thus $4.5 \%$ inclusion of sesame oil could be used in commercial production for healthier food demand by consumers.

\section{References}

[1] Rowghani, E., Arab, M., Nazifi, S. and Baktiari, Z. (2007) Effect of Canola Oil on Cholesterol Fatty Acid Composition on Egg-Yolk of Laying Hens. International Journal of Poultry Science, 6, 111-114. http://dx.doi.org/10.3923/ijps.2007.111.114

[2] Skrtic, Z., Kralik, G., Gajcevic, Z., Hanzek, D. and Bogut, I. (2008) Effect of Different Source of Oils on Fatty Acid Profile and Organoleptic Traits of Eggs. Acta Agriculturae Slovenica, 2, 129-134.

[3] Antongiovanni, M., Minieri, S., Buccioni, A., Galligani, I. and Rapaccini, S. (2009) Transfer of Dietary Fatty Acid from Butyric Acid Fortified Canola Oil into the Meat of Broiler. Italian Journal of Animal Science, 8, 754-756. http://dx.doi.org/10.4081/ijas.2009.s2.754

[4] Chowdhury, S.R., Chowdhury, S.D. and Smith, T.K. (2002): Effects of Dietary Garlic on Cholesterol Metabolism in Laying Hens. Poultry Science, 81, 1856-1861. http://dx.doi.org/10.1093/ps/81.12.1856

[5] Hargis. P.S. (1988) Modifying Egg Yolk Cholesterol in Domestic Fowl-A Review. World's Poultry Science Journal, 44, 17-19. http://dx.doi.org/10.1079/WPS19880002

[6] Agah, H.J., Nasriri-Moghaddam, H., Tahmasbi, A.M. and Lotfollahian, H. (2010) Performance and Fatty Acid Compositions of Yolk Lipid from Laying Hens Fed with Locally Produced Canola Seeds (Brassica napus L.). Research Journal of Biological Sciences, 5, 228-232. http://dx.doi.org/10.3923/rjbsci.2010.228.232

[7] Abdul-Rahman, S.Y., Abdulmajeed, A.F. and Alkatan, M.M. (2009) Effect of Sesame Seeds on Blood Physiological and Biochemical Parameters in Broiler Breeder Hens. Iraqi Journal of Veterinary Sciences, 23, 25-28.

[8] Kucukersan, K., Yesilbag, D. and Kucukersan, S. (2010) Influence of Different Dietary Oil Sources on Performance and Cholesterol Content of Egg Yolk in Laying Hens. Journal of Biological and Environmental Sciences, 4, 117-122.

[9] Fouladi, P., Salamat Doust, N.R., Ahmadzade, A., Aghdam Shahriar, H. and Noshadi, A. (2008) Effects of Canola and Sesame Oil on the Internal Organs and Carcass Weight of Broiler Chickens. Journal of Animal and Veterinary Advances, 7, 1160-1163.

[10] Wu, W.H., Kang, Y.P., Wang, N.H., Jou, H.J. and Wang, T.A. (2006) Sesame Ingestion Affects Sex Hormones, Antioxidant Status, and Blood Lipids in Post Menopausal Women. Journal of Nutrition, 136, 1270-1275.

[11] El-Tinay, A.H., Khattab, A.H. and Khidir, M.O. (2007) Protein and Oil Compositions of Sesame Seed. Journal of the American Chemical Society, 6, 648-653.

[12] MARD Vietnam (2010) QCVN 01-15:2010/BNNPTNT.

[13] National Resarch Concil (1994) Nutrient Requirements of Poultry. 9th Edition, National Academy Press, Washington DC.

[14] National Standards (2011) Vietnam Standard Feed (TCVN 8762: 2011)—The Method of Calculating the Energy Value Exchange in Compound Feed for Poultry.

[15] Mazalli, M.R., Faria, D.E., Salvador, D. and Ito, D.T. (2004) A Comparison on the Feeding Value of Different Sources of Fat for Laying Hens: 2. Lipid, Cholesterol and Vitamin E Profiles of Egg Yolks. The Journal of Applied Poultry Research, 13, 280-290. http://dx.doi.org/10.1093/japr/13.2.280

[16] Ergün, A., Yalçin, S., Colpan, I., Dikicioglu, T. and Yildiz, S. (1987) Utilization of Vetch by Laying Hens. Veteriner Fakultesi Dergisi, Ankara Universitesi, 34, 449-466.

[17] Botsoglou, N.A., Florou-Paneri, P., Botsoglou, E., Datos, V., Giannenas, I., Koidis, A. and Mitrakos, P. (2005) The Effect of Feding Rosemary, Oregano, Saffron and Alpha-Tocopheryl Acetate on Hen Performance and Oxidative Stability of Eggs. South African Journal of Animal Science, 35, 143-151.

[18] Cherian, G. (2008) Egg Quality and Polyunsaturated Fatty Acid Status in Relation to Broiler Breeder Hen Age and Dietary n-3 Oils. Poultry Science, 87, 1131-1137. http://dx.doi.org/10.3382/ps.2007-00333

[19] Nobakht, A., Safamehr, A., Sozany, S., Galandari, I., Taghavi, E. andGhaboli, I. (2011) Comparison of Effects of Us- 
ing Different Levels of Animal and Vegetable Fats and Their Blends on Performance of Laying Hens. Brazilian Journal of Poultry Science, 1, 1433-1437.

[20] Rasaulpour, A., Nobakht, A., Khodayi, S. and Mansoud, N.H. (2011) Effects of Graded Fat/Oil on Egg Production and Quality, Same Biochemical Parameters of Blood and Immunity in Laying Hens. Advances in Environmental Biology, 5, 1826-1831.

[21] Grobas, S., Mendez, J., Lazaro, R., Blas, C. and Mateos, G.G. (2001) Influence of Source and Percentage of Fat Added to Diet on Performance and Fatty Acids Composition of Eggs Yolks of Two Strains of Laying Hens. Poultry Science, 80, 1171-1179. http://dx.doi.org/10.1093/ps/80.8.1171

[22] Shafey, T.M., Dingle, J.G., Mcdonald, M.W. and Kostner, K. (2003) Effect of Type of Grain and Oil Supplement on the Performance, Blood Lipoproteins, Egg Cholesterol and Fatty Acids of Laying Hens. International Journal of Poultry Science, 2, 200-206. http://dx.doi.org/10.3923/ijps.2003.200.206

[23] Lelis, G.R., Silva, M.D., Tevernari, F.C., Albino, L.F.Z. and Rostagno, H.S. (2009) Performance of Layers Fed Diets Containing Different Diets. Brazilian Journal of Poultry Science, 11, 235-240.

[24] Mazalli, M.R., Faria, D.E., Salvador, D. and Ito, D.T. (2004) A Comparison of the Feeding Value of Different Sources of Fats for Laying Hens: 1. Performance Characteristics. The Journal of Applied Poultry Research, 13, 274-279. http://dx.doi.org/10.1093/japr/13.2.274

[25] Ceylan, N., Ciftci, I., Mizrak, C., Kahraman, Z. and Efil, H. (2011) Influence of Different Dietary Oil Source on Performance and Fatty Acids Profile of Egg Yolk in Laying Hens. Journal of Animal and Feed Sciences, 20, 71-83.

[26] Guclu, B.K., Uyank, F. and Iscan, K.M. (2008) Effects of Dietary Oil Sources on Egg Quality, Fatty Acid Composition of Eggs and Blood Lipids in Laying Quail. South African Journal of Animal Science, 38, 91-100.

[27] An, S.Y., Guo, M.Y., Ma, S.D., Yuan, M.J. and Liu, G.Z. (2010) Effect of Different Oil Sources and Vitamin E in Breeder Diet on Egg Quality, Hatchability and Development of the Neonatal Offspring. Asian-Australasian Journal of Animal Sciences, 23, 234-239.

[28] Milinsk, M.C., Murakami, A.E., Gomes, S.T.M., Matsushita, M. and de Souza, D.E. (2003) Fatty Acid Profile of Egg Yolk Lipids from Hens Fed Diets Rich in n-3 Fatty Acids. Food Chemistry, 83, 287-292. http://dx.doi.org/10.1016/S0308-8146(03)00094-3

[29] Balevi, T. and Cobkun, B. (2000) Effect of Some Dietary Oils on Performance and Fatty Acid Composition of Eggs in Layers. Revue de Médecine Vétérinaire, 151, 847-854.

[30] Pita, M.C.G., Carvalho, P.R., Neto, E.P. and Mendonça Jr., C.X. (2010) Effect of Marine Vegetal Sources on the Hen Diets on the PUFAs and PUFAs n-3 in Laying Hens Egg Yolk and Plasm. International Journal of Poultry Science, $\mathbf{9}$, 148-151. http://dx.doi.org/10.3923/ijps.2010.148.151 